\title{
MEMORY, TIME AND SPACE IN THE HYBRID STRUCTURES: MARCEL PROUST AND ORHAN PAMOUK
}

\author{
Slavica Srbinovska \\ Ss. Cyril and Methoduis University, Skopje \\ srbinovskas@gmail.com
}

This study attempts to interpret the function of memory through the structures of hybridized narration in Time Regained, the last volume of Marcel Proust's In Search of Lost Time, and Orhan Pamuk's Istanbul: Memories and the City. The subject's ability to remember is deeply connected to the temporalizing and spatializing acts of these novels. The narratorial subjectivity in both of these texts, constituted by a combination of the novel's fictional elements and the memoir's documentarian tendencies, registers the differences in the passage of time and space as a result of the reconstruction of meaning. They are both treated in relation to the process of recognizing the past. The narration of both novels insists on defeating these aspects of the phenomenal world, and re-conceiving them through a creative approach directed toward the recording of memories and the resisting of the destructive power of time. In both works, the self-analysis of the author plays a key role: a kind of procedure only made possible by the act of writing.

Keywords: subject, memory, time, space, narrativity 


\title{
МЕМОРИЈАТА, ВРЕМЕТО И ПРОСТОРОТ ВО ХИБРИДНИТЕ СТРУКТУРИ: МАРСЕЛ ПРУСТ И ОРХАН ПАМУК
}

\author{
Славица Србиновска \\ Универзитет „Св. Кирил и Методиј“, Скопје \\ srbinovskas@gmail.com
}

\begin{abstract}
Студијата го толкува значењето и ја актуализира функцијата на меморијата при конструирањето на приказната во наративна структура од хибриден вид, во која се активни фиктивните елементи на романот и документарните факти на мемоарите. Способноста на субјектот да меморира е во тесна врска со начинот на кој се претставуваат просторот и времето во рамките на еден текст со вакви жанровски одлики. Во студијата се става акцент врз последното дело на Марсел Пруст од циклусот романи Во йойраг̄a йо изгуубенойо време (1913-1927), насловено како Пронајоенойо време (1927), и врз мемоарите Истианбул: меморија и грая (2005) од Орхан Памук. Нараторот субјект и во двете дела настојува да ги регистрира разликите во времето и промените во просторот како резултат на реконструкцијата на значењата. Промените се во однос со процесот на неговото спознавање низ рефлексии за себе, но и со неговото толкување и перцепции на случувањата во времето, на луѓето и во просторот. Нарацијата во двете дела се обидува да ги совлада овие аспекти на егзистенцијата и да ја осмисли неа преку селективен и креативен пристап насочен кон зачувување на спомените и спротивставување на уништувачката моќ на времето. Во двете дела клучна улога има самоанализата, низ која нараторот доаѓ до сознанија за тоа дека смислата на животот може да биде исполнета единствено ако му се посвети на пишувањето.
\end{abstract}

Клучни зборови: субјект, меморија, време, простор, нарација 
Yes, if a memory, thanks to forgetfulness, has been unable to contract any tie, to forget any link between itself and the present, if it has remained in its own place, of its own date, if it has kept its distance, its isolation in the hollow of a valley or on the peak of a mountain, it makes us suddenly breathe an air new to us just because it is an air we have formerly breathed, an air purer than that the poets have vainly called Paradisiacal, which offers that deep sense of renewal only because it has been breathed before, in as much as the true paradises are paradises we have lost.

Marcel Proust, Time Regained

\section{Identity of the Subject: Time and Memory in Time Regained}

The entirety of In Search of Lost Time spans around three thousand pages. Published in the years between 1913 and 1927, this novel turns on the significance of a narrative "I" who embarks on a so called "search" of the past in order to "find and retrieve" his life that is irretrievably over. This search ends with the discovery of the role of narrative as the only force capable of bringing to life the events and people of the past. This novel is intended to contain segments of the past that are summoned by way of the experiences that flood the narrator's senses in the present. These involuntary memories of past events and their participants are a spontaneous evocation that portends a coming-to-terms with the numerous identities of the "I" in the narrative present, as well as the circumstances that induce them to change. The phenomenon of repetition, realized through the act of remembrance, does not mean the mechanic retrieval of dates with scenes and images of characters and events. The narrative "I" is presented before us at three positions in time that reflect mutable points of view. The perspective of representation produced by the "I" of the narrator is occasionally that of an adult; occasionally one of a hero who directly involves himself into a part of the realm of the past; and sometimes one of an omniscient narrator who represents events in which he has not been a participant. The relationship of the narrator with time is not an expression of his acceptance of the historical flow and continuity of time in three dimensions-of yesterday, today, and tomorrow. He vertiginously binds himself to the hours, days, and years without labeling them with dates, and insisting on "finding" them and "retrieving" them through an intense experience activated by the senses that bring to life both monument and memory. What secures a victory over time is the act of inscription-of the writing of a book with all these events which sporadically and unannouncedly "occur" in the scene of writing. From this perspective, in which consciousness takes shape, they appear as atoms of time, as fragmentary flashes induced by inner feelings about the happenings of the past. They are not rationally reproduced through the efforts of memory (Watt 2013: 99). In their spontaneous evocation, the discovered fragments of time become composite parts of the novel that Proust decides to write, and in so doing, they illuminate and help him interpret the making of meaning in the careening relationship between past and present. 
As the narrator's reflections in the last part of the novel, titled Time Regained, time can be characterized by the continual repression of the present into the past. A characteristic of time becomes the maintenance of the content in a certain present moment that remains in the narrator's hands for a little while longer; but soon abandons him, as it is repressed into a new present moment and sinks into oblivion, farther and farther away from conscious understanding. In this novel, narration becomes an exciting adventure about the retrieval of the segments of time, of events and spaces, of more than one hundred and seventy one characters. In the dynamism of time's flow, they all transform, as the narrator does.

Marcel Proust still insists on this effect of temporal layers alongside the phenomenon of the search and discovery. In the segments of time filled with an event that spurs on the senses of scent or taste, memory activates itself, and the evoked event slowly actualizes itself in such a way that brings us to think of it as happening in the present, before our eyes. These are moments of the exclusion of consciousness from the flow of historical time, and of a surrender to the instance of timelessness, in which the layers of the past and the present intertwine. The feeling that spurs on the crossing of the present with the memory of the past is followed by the pleasure that arises from the understanding that this manner of relation is achieved through a victory over forgetting. The overlap between the "I" that remembers and the "I" that is the object of memory purges the temporal distance in an act that founds the novel as a genre based on the practice of search and discovery (Kasell 1980: 81). The reading of the novel means an entry into a combination of events connected to the mental, psychological constitution of the aristocracy and bourgeoisie, the political and artistic life, areas, places, and landscapes of France. Reading the novel means to encircle contents that transpire directly in front of the eyes of the narrator-events in which he is also a participant, contents that reflect on him and constitute him in the act of summoning the past. The distance from the past and the proximity of the present surpass each other in the moments in which the experiences of timelessness or simultaneity emerge Marcel Proust is among the first artists in the twentieth century who emphasizes the role of writing's reflection on the artist who is writing. After him, this role becomes dominant not only in the novel, but also in music, painting, and sculpture. The effect of the past's simultaneity, the confluence of the past and the future in the moment of experience, and the reflection on that experience are procedures that Proust actualizes in relation to the power of art. He leaves behind a novel of about three thousand pages, an artificial version of the realization of a totality that the human of the twentieth century will no longer be able to realize. The potential of memory is activated through art in the novel and its procedural shaping. The reflections on time and on memory in the last part of the novel, Time Regained, and the coming-to-terms with the people whose presences have shaped the narrator's life, and who are represented during a matinee in the Guermantes' home, are connected to the form of the novel. The art of writing is, in fact, the space where all past events can come to life. It is the site of analysis, where reader and writer come together, constitute each other, and discover difference as the basis of meaning-making in the world. In reflecting on the relationship between art and time, the narrator says: 
Finally, this idea of Time had the ultimate value of the hand of a clock. It told me it was time to begin if I meant to attain that which I had felt in brief flashes on the Guermantes' side and during my drives with Mme. de Villeparisis, that indefinable something which had made me think life worth living. How much more so now that it seemed possible to illuminate that life lived in darkness, at last to make manifest in a book the truth one ceaselessly falsifies. Happy the man who could write such a book. What labour awaited him. To convey its scope would necessitate comparison with the noblest and most various arts. For the writer, in creating each character, would have to present it from conflicting standpoints so that his book should have solidity, he would have to prepare it with meticulous care, perpetually regrouping his forces as for an offensive, to bear it as a load, to accept I as the object of his life, to build it like a church, to follow it like a régime, to overcome it like an obstacle, to win it like a friendship, to nourish it like a child, to create it like a world, mindful of those mysteries which probably only have their explanation in other worlds, the presentiment of which moves us most in life and in art (Proust 2003: 192).

In the last part of the novel, the narrator consciously points to the significance of memory and its inscription-a self-same way of defeating the fear that life has ended without a trace, that all events have happened and remain suppressed deeply in the past, slowly sinking into oblivion. Proust recognizes that the specific powers of the senses, in the right moment, can resurrect the past and return it. The book, according to the narrator, enables the coming-to-life and inscription of the past so that it can be saved from its destruction. The end of this section contains reflections that attempt to illuminate the theory of the novel that the author exhibits in his effort to explain his own understanding of the relationship between life and art. The explanations of the narrator, as they are connected to the book that he wishes to write, justify the very act of creation as a victory over oblivion. The remembering "I," which is also an object of remembrance in In Search of Lost Time, the narrator and the reader, all compose a unity in the bringing-together that Time Regained enacts (Brown 2004: 175).

The theoretical reflections on this book help us understand the experience of reading this novel. Through it, the readers find themselves in a state in which they grapple with the great incompleteness of being. The narrator says:

From this point of view and so as not to allow myself to be deceived by the apparent identity of space, the perfectly new aspect of a being like M. d'Argencourt was a striking revelation of the reality of the era which generally seems an abstraction, in the same way as dwarf trees or giant baobabs illustrate a change of latitude. Then life appears to us like a fairyland where one can watch the baby becoming adolescent, man becoming mature and inclining to the grave. And, since it is through perpetual change that one grasps that these beings, observed at considerable intervals, are so different, one realises that one has been obeying the same law as these creatures which are so transformed that they no longer resemble, though they have never ceased to be-just because they have never ceased to be-what we thought them before (Proust 2003: 133).

The act of recognition in relation to the multitude of images of people and events from the past, connects those people and events to the present. These images differ 
and contradict each other. In the end, parallel to the tendency of transcending time runs the consciousness of a human essentially determined by time and its unstoppable flow and influence. Proust's idea of the human, of art and time, indicates the understanding that life goes on, and a big part of that life, for the characters of Time Regained, has passed. Against this realization, he ever increasingly emphasizes the faith in writing as the site of recognition and shaping of the past, of the return to those episodes of life that have thus far been absent, because each of them in one period or another end and are replaced with new ones. The only thing that remains in the end is the fear that the narrator will run out of time. On a formal level, the novel ends and the book closes. But the closing of the book is a new opening, as the novel begins to become inscribed into the dream-logics of memory that the story of In Search of Lost Time has been thematizing (Kern 1983: 291). The remembrances of childhood, which is long gone, and with which the cycle of the novel begins, reappears at the novel's end too. The circle of contents that relate to the question of time closes; the narrator's father is no longer alive and the house in which he lived with his parents no longer exists. The sense of an ending arises from the living feeling of the contents of the past, of the restraint from crying before the father when the narrator was a child, as he stood in front of a window that gathered the falling light of the moon, or as he expected his parents' appearance after they've seen Swann to the door that opens into the garden with the ringing of the bell. In the internal world of the adult narrator, the sound of the bell resounds as though it were transpiring before him.

This repeated remembrance of the scene of falling asleep, which begins to develop the theme of time in the novel, enables the coming-to-terms with the destructive power of time, and the discovery of the motivation to write a novel composed of all those living scenes that we have come to associate with Proust's magnum opus. The discovery of time in relation to power is an attempt to bring all forgotten events back through the forms of art with the passing of the bridge which spans the first part of the novel (Hayssen 1995: 4). In this novel, Proust shows that it only appears that the piling of the years that drag us away from the past bring about its disappearance. In fact, this is only the case until that unexpected moment arrives in which the layers of difference that constitute memory become unraveled and the past intervenes into the present moment. The past, for Proust, lives in us, and speaks through us, but needs to be overheard, in the moment of intense feeling that brings about the act of inscription.

In Time Regained, Proust encircles the understanding of the role of memory as a movement produced by the senses. The deep sense of melancholy that he evinces bespeaks the kinds of change that the flow of time causes in people. At the same time, through a new and mature point of view of a man who has chosen to become a writer and to analyze the people who have surrounded him, those whom he has admired, but also those who are irretrievably destroyed by the passage of the years, he returns them to us and to himself through the act of writing. 


\section{Space and Melancholia: Hüzun and Istanbul: Memories and the City}

A number of decades later, in the city of Istanbul, Orhan Pamuk reflects on his decision to become a writer just like Marcel Proust. His autobiographical novel Istanbul: Memories and the City, tells a story of a place that has profoundly shaped the story's narrator. In his story, Pamuk uses photographs, a visual structural component of the narration, a component that insists on the impact of space on people. Melancholy in Pamuk has been transformed into a text, and thus eternalized in the form of description, event, and image. Here, my argument turns to Pamuk, whom I see as an inheritor of Proust's intellectual and affective projects. I argue that Pamuk's acts of spatialization in the novel constitute the novel as a visual archivean archive that undoes the boundaries between private and public, and that thematizes the effects of a paradoxical memory that disappears.

"If I see my city as beautiful and bewitching," says the narrator of Orhan Pamuk's Istanbul: Memories and the City, "then my life must be so too" (Pamuk 2005: 52). What is striking here is how space and memory not only fascinate this autobiographical novel, but also become central, constitutive notions of its import, activating a number of serious ontological and political implications. The term "novel" here designates an emphasis and insistence on the selective approach to facticity that makes this account of narrated selfhood dominate the story and, in so doing, obscure notions of objective reality for us. This book defies generic definitions; its aesthetic sensibility arises in part from its hybridity and ambiguity with respect to its genre. Here I would like to think about the concept of "changing the world", setting aside the possibly spacious affordances of that phrase, to focus strictly on what Pamuk's narrative offers us. What kind of original approach do we encounter in telling a story devoted to the city, built by narrative memory as much as it is recounted by it? What we encounter, when we focus most strictly on the narrative provisions of the text, is not so much the emergence of a genre, but the emergence of a particular type of history, a history that can just as particularly disappear. I use the term history here to specify a kind of social world indexed by Pamuk's prose, one constituted by the novel's distribution of affect in relation to memory. Hüzün, or melancholy, emerges as a central affective structuring principle of Pamuk's story. Istanbul constitutes such a site where the interlacing feelings of suffering and pleasure that constitute hüzün meet. The city's vibrant presence, its unlikely but meaningful combinations of joy, violence, ritual, is for Pamuk the result of a decision to carry the burdens of hüzün willingly.

Even Gérard de Nerval (whose own melancholy would eventually drive him to suicide) spoke of being greatly refreshed by the city's colors, its street life, its violence, and its rituals; he reported hearing women laughing in its cemeteries. Perhaps it is because he visited Istanbul before the city went into mourning, when the Ottoman Empire was still in its glory, or perhaps it was his need to escape his own melancholy that inspired him to decorate the many pages of Voyage en Orient with the bright eastern fantasies. Istanbul does not carry its hüzün as "an illness for which there is a cure" or 
an unbidden pain from which we need to be delivered': It carries its hüzün by choice. And so it finds its way back to the melancholy of Burton, who held that 'All other pleasures are empty. /None are as sweet as melancholy'; echoing its selfdenigrating wit, it dares to boast of its importance in Istanbul life. Likewise, the hüzün in Turkish poetry after the foundation of the Republic, as it too expresses the same grief that no one can or would wish to escape, an ache that finally saves our souls and also gives them depth (ibid., 85).

In thinking about the triangulation of memory, the city, and melancholy; the long, chronic efforts to discredit Pamuk's work; and his own efforts to break away from the social realist tradition, we find a new, politicized way to read this book. Indeed, this is precisely the site where, despite his self-identifying as apolitical, Pamuk's work becomes political (Star 2004). It is true, without a doubt now, that Pamuk's writings have been, for a long time, provocations for the Turkish national imaginary. Comments against Pamuk have become rather commonplace, particularly in the last decade, in mainstream media, among those segments of society that align themselves with a specific Turkish brand of ultranationalism. And what has made Pamuk a thorn in their sides is precisely his refusal to articulate a stable politic, his questioning of literature's moral orientations, and more specifically, the novel's political responsibilities. He rarely chooses a position; rather, his work is to work-through, or simply illuminate, paradoxes, ambivalences, and contradictions that arise in the taking of a certain political stance.

While Pamuk's work is certainly reflective of a significant rupture in novelistic production in Turkey, he is hardly alone at work in this effort. Berna Moran (2002), Ahmet Evin (1983) and Azade Seyhan (2008) describe a palpable shift in the post1980 novel in Turkey in terms of both content and style. The economic and sociocultural transformation ensuing the 1980 military coup, which prompted a period of coercion and liberalization at the same time, also produced a new vision of what literature could be. Along with the effects of the postmodern turn on literary production, this new vision culminated in a diversion from social realism and a focus on the individual. There also appeared an interest in narrative experimentation that included nonlinear storylines, inconsistent character developments, erasure of the omniscient narrator, intertextuality and self-reflexivity. Authors such as Latife Tekin, Bilge Karasu, Nazlı Eray, Buket Uzuner, Pınar Kür, Murathan Mungan, İhsan Oktay Anar, Elif Şafak are among the representatives of this new movement in novel-writing. First, however, we need to understand what melancholy actually means in Istanbul. The structuring image and example of this pursuit will be the photograph of him as a five-year-old boy. 


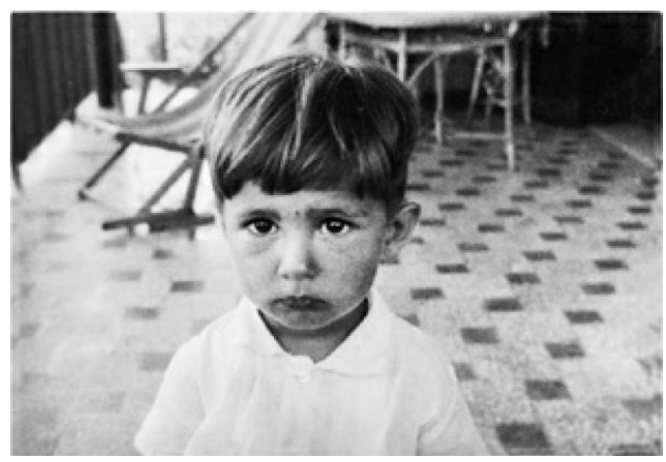

Photo 1. The portrait of the artist

When I was five I was sent to live for a short time in another house. After one of their many stormy separations, my parents arranged to meet in Paris, and it was decided that my older brother and I should remain in Istanbul, though in separate places. My brother would stay in the heart of the family with our grandmother in the Pamuk Apartments, in Nişantaşı, but I would be sent to stay with my aunt in Cihangir. Hanging on the wall in this house-where I was treated with the utmost kindness - was a picture of a small child, and every once in a while my aunt or uncle would point up at him and say with a smile, 'Look! That's you!'

The sweet doe-eyed boy inside the small white frame did look a bit like me, it's true. He was even wearing the cap I sometimes wore. I knew I was not that boy in the picture (a kitsch representation of a 'cute child' that someone had brought back from Europe). And yet I kept asking myself, Is this the Orhan who lives in that other house? (ibid., 14)

This insular passage, appended to a "kitschy image" of a European child that has been brought back to the Pamuk's home in Cihangir, presents us with what we might call a model for the kind of work that the novel will attempt to do. Hung at the end of the first paragraph is an apostrophe that hails the young child, in the manner of a playful address, into a complex structure of specularity. The child sees the photograph, and begins to discern details that would make "the sweet doe-eyed boy inside the small white frame" look like him. And at the same time when the specular structure has been constituted, and little Orhan begins to see himself as that boy, that structure becomes undone. Little Orhan is no longer the boy in the picture, but wonders if he is perhaps the boy who lives in the other apartment. Under the name of the subject "Orhan" live multiple different personalities and identities. The checkered floor behind the dour European boy, seemingly endless in its recombinant recursion, be speaks symbolically the endless repetition of memories, layered like photographic plates, that constitute that endlessly multiple subject. In the flash of the photograph, a moment gone just as it happens, the subject has been captured as that which he will never be again. It should not surprise us, then, to find hüzün in Pamuk's novel. What makes the novel's spatializing acts deeply embedded in the affective practices of melancholy is the locus of Istanbul itself. As a 
matter of fact, what makes Istanbul a sophisticated and compelling site of elegiac writing is the way it demonstrates, and in fact impels us to reflect upon, the complexities of mourning-a confusing, tumultuous, ambivalent affective procedure that occurs in a number of genres-some of which remain too hazy and perhaps even impenetrable to other forms of knowledge.

This personal trajectory initially unfolds as vestibular to the collective ones of the Middle East. With Istanbul's transformations in the $20^{\text {th }}$ century, the dissipation of the Ottoman Empire and the concomitant outflow of wealth from the city, all function as a kind of background for the appearance of melancholia in Istanbul. Pamuk writes:

After seeing all the wealth of the Middle East seep out of their city, after witnessing the slow decline that began with the Ottoman defeats at the hands of Russia and the West and ended with their city falling into poverty, melancholy, and ruin, Istanbullus became an inward-looking nationalist people; we are therefore suspicious of anything new and most especially of anything that smacks of foreignness (even if we also covet it). For the past 150 years, we have lived in timorous anticipation of catastrophes that will bring us fresh defeats and new ruins. It's still important to do something to fight off the dread and the melancholy, and that is why the idle contemplation of the Bosphorus can seem like a duty. The types of disasters that the city remembers best and awaits with greatest trepidation are, of course, the accidents involving ships in the Bosphorus. These bring the city together and make it feel like a large village. Because these disasters suspend the rules of everyday life and because, in the end, they spare "people like us," I secretly (if also guiltily) enjoy them (ibid., 155).

Working with Dominick LaCapra's similar, but not identical, reading of Freud's distinction in Mourning and Melancholia where mourning is a practice by which the surviving subject comes to find a way to incorporate loss in his life, and melancholia represents a subject's fixation on that very loss, I wonder here if it is possible to make a similar claim about Pamuk's melancholy speaker, for whom, “...hüzün is the smoky window between [the poet] and the world. The screen he projects over life is painful because life itself is painful" (ibid., 85). Locked in compulsive repetition, possessed by the past, his turn to a literary language that distinctively refuses the register and footing of realist fiction enables him to invent a society that will remember, rather than simply re-enact and unconsciously repeat, the injuries that lie at its heart (LaCapra 2014: 106).The assessment that LaCapra has leveraged over the melancholic subject, describing him as necessarily a narcissist who cannot help but engage with his past, has been challenged by a number of scholars, suggesting that perhaps melancholia can constitute a generative, and even productive affect. What constitutes "melancholy proper" for Žižek, is that it "designates the attitude of those who, although still in a closed universe, already possess a vague premonition of another dimension which is just out of their reach" (Žižek 2012). Apart from drawing attention to this latent potential in melancholia a la Benjamin, scholars from different disciplines have thought differently about the possibilities 
of mourning, defined in opposition to melancholia, suggesting that melancholia does not have to constitute an abandoning or forgetting of the lost object, but a commitment to and insistence on the refusal to let go of it, a kind of mourning with a chronic dimension to it. In Pamuk's novel, everything is narrated in a parallel universe of discourses of the words and of the photography of the city. We present this rhetorical approach by citing the narration and the photography correspondent to the words:

And with this attraction to the shadow world, I have always preferred the winter to the summer in Istanbul. I love the early evenings when autumn is slipping into winter, when the leafless trees are trembling in the north wind and people in black coats and jackets are rushing home through the darkening streets. I love the overwhelming melancholy when I look at the walls of old apartment buildings and the dark surfaces of neglected, unpainted, fallen-down wooden mansions; only in Istanbul have I seen this texture, this shading (Pamuk 2005: 36).

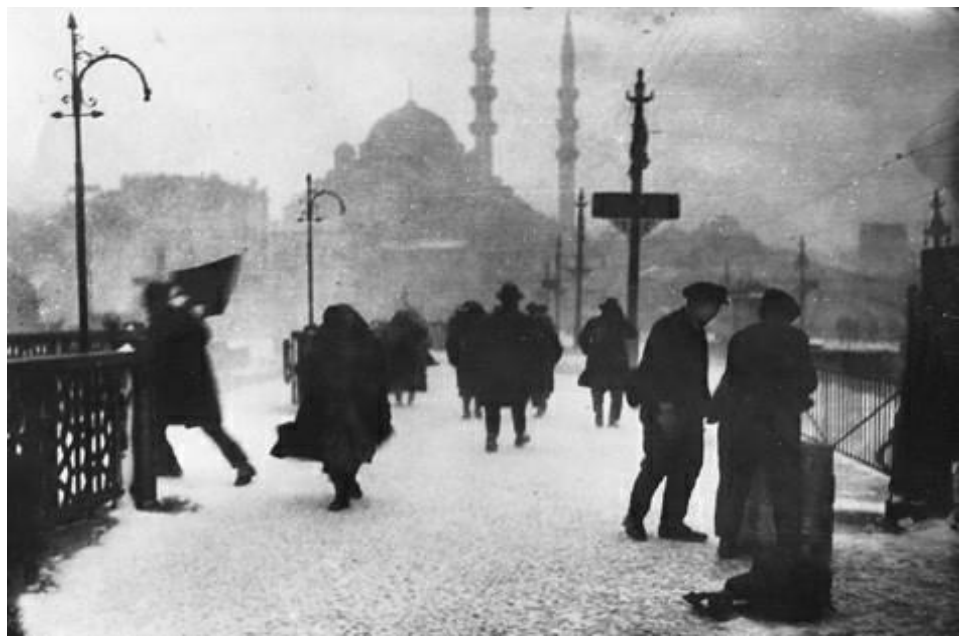

Photo 2. Winter in Istanbul

Darian Leader suggests that since melancholy is not a blocked, arrested or failed form of mourning but a structurally different category on its own, the healing process must follow a different path than that of the work of mourning. In other words, he suggests that the remedy lies not so much in the attempts to transform melancholy into mourning, but in "finding ways to designate [...] the impossibility of the melancholic's own position inhabiting two worlds" (Leader 2009: 101). More concretely, such a procedure might entail discovering creative ways to express how words (or symbolization, in more general terms) fail instead of searching for the right words that correspond to and delineate the melancholic's situation. Within this framework, what I ultimately wish to argue here argue is that in Istanbul, Pamuk enacts melancholic speech in the very form of the text and does so in a way that reveals the creative vein in hüzün. Here hüzün becomes a procedure akin to but 
not identical with Proust's attempt to search for the past, and ultimately to regain time. Hüzün possesses a spatio-historical quality that is tethered to the city of Istanbul and concatenated with the rise of postmodernism. In another part of his book, Pamuk usesa similar spatializing approach by narrating and by showing:

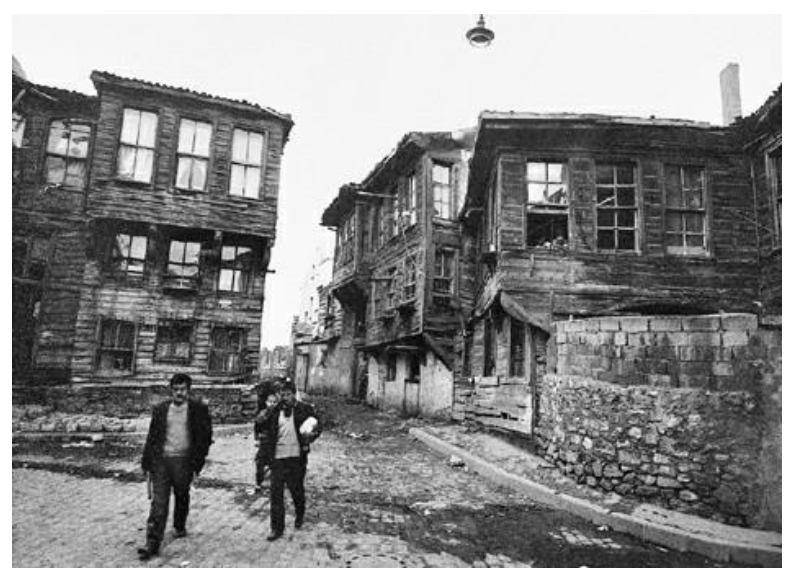

Photo 3. Hüzün of Istanbul

Montaigne's own sorrow was as solitary as mourning, eating away at the mind of a man who lives alone with his books. But the hüzün of Istanbul is something the entire city feels together and affirms as one. Just like the heroes of Tanpinar's Peace, the greatest novel ever written about Istanbul: Because of the hüzün they derive from the city's history, they are broken and condemned to defeat. It is hüzün which ordains that no love will end peacefully. Just as in the old black-and-white films - even in the most affecting and authentic love stories-if the setting is Istanbul, it is clear from the start that the hüzün the boy has carried with him since birth will lead the story into melodrama (Pamuk 2005: 86).

The difficulty of the ontological burden that disables the speaker from experiencing the loss in such a way that he is able to leave it behind, produces a series of vertiginous effects. The passage begins with a photograph of two men departing from the narrow alley bracketed by buildings in various states of disrepair. They appear to be walking out of the image, bound together by a melancholy experience that doesn't simply belong to a single subject. Melancholia, in Freud, seems to undo the subject and bring it into the circulation of a subjectivity writ large (Freud 1957: 243-259). Hüzün, however, proceeds from the collective, and brings into question not only the subject but also subjectivity as such. The issue that the passage that follows the photograph foregrounds, however, is a way of thinking about a way through and outside the suffering that constitutes hüzün. What belongs most properly to the formal contours of melancholy is a repeated longing, a lack at the heart of speech that thwarts expression and disables knowledge. And narration, the 
act of inscription, and the photographic plate, prove to be material responses to the organizing principles of hüzün from within it.

In this novel, Pamuk attempts to suspend and alter the meaning of change itself. In a Proustian way, he attempts to return moments from the past-moments in which one's life, situated in a specific space, between particular objects, can come alive in writing. It is that voice, cultivated in writing, that can resuscitate the past into a meaningful narrative in the present. In this way, he problematizes the very stakes of memory as a matter of evidence. Memory, in Pamuk, works as a technique of melancholia to segment sequences of life in Istanbul in the twentieth century. This segmentation produces specific, localized images rather than grand narratives. The novel's work is then to problematize the status of narrative perspective itself-the one of the aged narrator and the one of the boy from the past. The treading of the existential distance between the two can be likened to the work of an archival researcher, who, sifting through the entries in a dossier, remains suspended between truths and must only ever raise questions about fact, which belongs to the regime of space, and ficton, which belongs to the regime of text. This is how Pamuk's text raises the issue of inscription as a practice that not only recollects, but also produces memories.

\section{References}

Berna, M. (2016). Türk Romanına Eleştirel Bir Bakış - 2. İstanbul: İletisimYayınları.

Boulter, J. (2011). Melancholy and the Archive. Trauma, Memory, History in the Contemporary Novel. New York: Continuum international publishing group.

Brown, S. G. (2004). The Gardens of Desire. Marcel Proust and the Fugitive Sublime. Albany: University of New York Press.

Carter, W. C. (2004). The Vast Structure of Recollection: from Life to Literature. In H. Bloom (ed.). Marcel Proust. Philadelphia: Chelsea House Publishers.

Evin, O.A. (1984). Origins and Development of the Turkish Novel. Studies in Middle Eastern Literatures. Bibliotheca Islamica.

Freud, S. (1957). On the History on Psycho-Analytic movment. Papers on Metapsychology and Other Works. Volume XIV (1914-1916). (Translated by James Strachey in collaboration with Anna Freud). London: The Hogarth Press and the Institute of Psycho-Analysis.

Hand, S. (1989). The Levinas Reader. Oxford and Cambridge: Basil Blackwell.

Hodson, L. (1989). Marcel Proust: The Critical Heritage. London and New York: Routledge.

Huyssen, A. (1995). Twilight Memories: Marking Time in a Culture of Amnesia. New York: Routledge.

Kasell, W. (1980). Marcel Proust and the Strategy of Reading. Amsterdam: John Benjamins B.V.

Kern, S. (1983). The Culture of Time and Space. Massachusetts: Harvard University Press.

LaCapra, D. (2014). Writing History, Writing Trauma. Baltimore: Johns Hopkins University Press.

Leader, D. (2009). The New Black: Mourning, Melancholia and Depression. Minneapolis: Graywolf Press. 
Pamuk, O. (2005). Istanbul: Memories and the City. (Translated from the Turkish by Maureen Freely). New York: Alfred A.Knop.

Painter, G. D. (1989). Marcel Proust. A Biography. New York: Random House.

Seyhan, A. (2008). Tales of Crossed Destinies: The Modern Turkish Novel in a Comparative Context (World Literatures Reimagined). New York: Modern Literature Association of America.

Star, A. (2004). Interview. Orhan Pamuk: 'I Was Not A Political Person'. New York Times, August $15^{\text {th }}$.

Watt, A. (2013). Marcel Proust. London: Reaktion Books.

Proust, M. (2003). Time Regained. (Translated by Stephen Hudson). [Online] Available from: http://gutenberg.net.au/ebooks03/0300691.txt [Accessed: November $6^{\text {th }}, 2019$ ]

Žižek, S. (2012). The Optimism of Melancholia. Interview by Big Think, Jonathan Fowler and Elizabeth Rodd. [Online] Digital Video. Available from: https://www.youtube.com/watch?v=eUIjoYDKETM [Accessed: November $6^{\text {th }}, 2019$ ] 